\title{
The Size of Countries: Does it Matter?
}

\section{Citation}

Alesina, Alberto. 2003. The size of countries: Does it matter? Journal of the European Economic Association 1, no. 2-3: 301-316.

\section{Published Version}

http://dx.doi.org/10.1162/154247603322390946

\section{Permanent link}

http://nrs.harvard.edu/urn-3:HUL.InstRepos:4551794

\section{Terms of Use}

This article was downloaded from Harvard University's DASH repository, and is made available under the terms and conditions applicable to Other Posted Material, as set forth at http:// nrs.harvard.edu/urn-3:HUL.InstRepos:dash.current.terms-of-use\#LAA

\section{Share Your Story}

The Harvard community has made this article openly available.

Please share how this access benefits you. Submit a story.

Accessibility 


\title{
JoSEPH SCHUMPeTER LeCTURE THE SIZE OF COUNTRIES: DOES IT MATTER?
}

\author{
Alberto Alesina \\ Harvard University, \\ NBER, and CEPR
}

\begin{abstract}
Borders are a man-made institution, and as such their shape cannot be taken as part of the physical landscape. The size of countries is endogenous to politico-economic forces. This paper discusses recent efforts by economists to study three related questions: What determines the evolution of the size of countries? Does size matter for economic success? Given the trend toward decentralization and of creation of supernational unions such as the EU, is the meaning of national borders evolving? (JEL: H10)
\end{abstract}

\section{Introduction}

Economists, even those who study international relations, take the borders of countries as exogenously given, like a geographic variable. Instead, borders are a man made institution, and, as such, should not be taken as part of the physical landscape, like mountains and rivers. In fact even the geographic nature of a country in a sense is man made: for instance, whether a country is landlocked or not depends on human choice about borders. Bolivia was not landlocked until it lost part of its territory to Chile in 1884. If Lombardy declared a unilateral secession from Italy it would be landlocked.

When thinking about long-term phenomena, such long-run growth, the pattern of international trade, the role of geography for economic development, civil wars, political stability, institutional and economic development, and one cannot take national borders as given. This paper discusses how to make progress in studying the configuration of borders as an endogenous variable. Throughout this essay I will use the words nation, country and state interchangeably to mean "sovereign state" in the modern sense of the world. In particular I am not dealing with the concept of a "nation" as people without a territory and a government.

Let's start with a few general observations. First, the size of countries is very diverse. China, the largest country in the world has 1.2 billion inhabitants; Tuvalu, the smallest country with a seat in the UN has 11,000 inhabitants.

Acknowledgment: This lecture is based upon joint work with Enrico Spolaore, especially Alesina and Spolaore (2003).

E-mail address: Alberto.alesina@uni_bocconi.it 
Second, borders change relatively frequently. In 1946 there were 76 independent countries in the world; today there are 193. This number includes all the countries with a seat in the UN plus Taiwan and Vatican City. If one includes various other protectorates such as Puerto Rico, semi-independent territories, etc., one reaches a much higher number.

Thus, in the last half a century the number of countries has almost tripled. Even when secessions did not occur, political separatism remains a critical political issue in many countries including Canada, Spain, Russia, and the United Kingdom, just to name a few OECD examples. Issues of ethnic conflict and separatism are very common in Africa. India faces various centrifugal tensions. One could continue. On the other hand, while in most parts of the world separatism seems to be the dominant tendency, Germany and Yemen have reunited.

Third, the meaning of national borders is also changing in two ways. On the one hand, one observes a tendency toward decentralization around the world. "Decentralization is in vogue" as Oates (1999) notes in a recent review essay. In fact increasing decentralization is often a response to separatist threats, as in Spain or Italy. At the same time supernational unions of countries are becoming more common; from regional trade agreements like NAFTA or Mercosur, to the GATT, to common currency areas, in addition to those organizations already in place for several decades like NATO, or the UN. For a broad discussion of the current evolution of currency unions around the world and their economic effects, see Alesina, Barro, and Tenreyro (2002).

A particularly striking and unique example in this respect is the European Union. More than even before, Europe is moving toward a complex organization of layers of government and borders. For instance a typical European citizen is governed by a series of up to six levels of governments, from a city council to the European Union, and one could view the national government as just one of them. However, the national government does maintain a key characteristic that is the monopoly of coercion within its borders and for this reason retains a key role in this system of governments and national borders maintain some key properties.

These observations raise three related questions. What determines the size of countries and how does country size evolves as a function of various politico-economic forces? Does size matter? In particular does it matter for economic success, and if so, how? How is the role of the central government and of national borders evolving?

I now address these three questions.

\section{The Size of Countries}

While economists have largely ignored the question of country size, philosophers, political scientists, and historians have devoted much intellectual energy to this topic. 
Greek philosophers emphasized the benefits of small and homogeneous polities. Plato calculated the optimal size of a polity down to the precise number of households, namely 5,040 heads of families. Aristotle argued that a polity should be no larger than a size in which everybody knows personally everybody else. In fact, he argued in The Politics that "experience has shown that it is difficult, if not impossible, for a populous state to be run by good laws." This Greek view of a small polity, in which everybody knows each other and therefore is very homogeneous, often resurfaces in later philosophers, such as Montesquieu. The Founding Fathers of the United States often referred to Montesquieu's views when they worried about the "excessive" size of the new federation. In response to these fears James Madison devoted much intellectual energy in order to argue against those contemporaries that felt that the United States was too big and diverse to be a feasible state. Dahl and Tufte (1973) also discuss at length the (positive) relationship between homogeneity and politics.

The classical philosophers' thinking about the size of nations has a normative nature. Historians have instead studied the evolution of the states often emphasizing the role of wars in the creation of new states. As Tilly (1990) emphasized, military conflicts and military technology are crucial for the pattern of state formation. Economists, at least until very recently, have not worried about explaining national borders. One isolated attempt for the case Medieval Europe is Friedman (1977).

One way of thinking about the size of a state is the trade off between the benefits of size versus the costs of heterogeneity of preferences, culture, attitudes of the population. This key trade-off helps us both in defining the "optimal" size and the equilibrium size, that is, it is useful from both a normative and a positive perspective.

What are the benefits of having a large size? First, the per capita costs of many public goods are lower in larger countries, where more taxpayers can pay for them. Think, for instance, of defense, a monetary and financial system, a judicial system, infrastructures for communication, police and crime prevention, public health, embassies, and national parks just to name a few. In many cases, parts of the costs of public goods are independent of the number of users/tax payers, or grow less than proportionally, thus the per capita costs of many public goods is declining with the number of taxpayers. Alesina and Wacziarg (1998) document that the share of governments spending over GDP is decreasing with GDP; that is, smaller countries have larger governments, even after controlling for several other determinants of government size.

Second, a larger country (in terms of population and national product) is less subject to foreign aggression. Thus, safety is a public good that increases with country size. Also, related to the "size of government" argument here, smaller countries may have to spend proportionally more for defense than larger countries given the economies of scale in defense spending. Empirically the relationship between country size and share of spending of defense is affected by the fact that small countries can enter into military alliances, but in general, 
size brings about more safety. In addition, if a small country enters a military coalition with a larger one, the latter may provide defense, but it may extract some form of compensation, direct or indirect, from the smaller partner.

Third, the size of the country affects the size of their markets. To the extent that larger economies and larger market increase productivity, then larger counties should be richer. In fact, a large literature on "endogenous growth" emphasizes the benefits of scale. Fourth, large countries can provide "insurance" to their regions. Consider Catalonia, for instance. If Catalonia experiences a recession, which is worse than the Spanish average, it receives fiscal transfers, on net, from the rest of the country. Obviously, the reverse holds as well; when Catalonia does better than average it becomes a provider of transfers to other Spanish regions. If Catalonia, instead, were independent it would have a more pronounced business cycle because it would not receive help during especially bad recessions, and would not have to provide for others in case of exceptional booms. The size of these interregional transfers which operate through several channels of the fiscal code and of spending programs, are, in fact, quite sizable. The benefits of insurance are even more obvious in the case of natural calamities; an independent Catalonia hit by a disaster would probably receive less help as an independent country than as a region of Spain. Obviously the reverse would also be true.

Fifth, there can be positive or negative externalities amongst regions. Being part of the same country allows for an internalization of externalities.

Finally, large countries can build redistributive schemes from richer to poorer individuals and regions, therefore achieving distributions of after tax income, which would not be available to individual regions acting independently. This is why poorer than average regions would want to form larger countries inclusive of richer regions, while the latter may prefer independence. Thus, it may very well be that a region richer than the average of the country, take again, the example of Catalonia, may end up, on average, to transfer resources to the poorer regions.

If there were only benefits from size, then the tendency should be for the entire world to be organized in a single country. This is not the case. Why? As countries become larger and larger, administrative and congestion costs may overcome the benefits of size pointed out previously. However, these types of costs are likely to become binding only for very large sizes; they do not seem to be what determines the observed size of countries, many of which are quite small. The median country size is less than six million inhabitants.

Much more important are the facts that as countries become larger, diversity of preferences, culture, language, "identity" of their population increases. In one word, heterogeneity of preferences increases with size. Being part of the same country implies agreeing on a set of policies: from redistributive schemes, to public goods to foreign policy; as heterogeneity increases, more and more diverse individuals will have to agree on them. Certain policies can be delegated to localities in order to allow for diversity, but not every policy can be local; 
think of foreign policy for instance. As heterogeneity increases, then, more and more individuals or regions will be less satisfied by the central government policies. In fact many harsh domestic conflicts are associated with racial, religious, and linguistic heterogeneity and have threatened the stability of national governments. Easterly and Levine (1997) have documented convincingly how ethnic heterogeneity often interferes with the implementation of good and growth enhancing policies. La Porta et al. (1999), show that various measures of quality of governments in a cross-section of countries are generally inversely related to the degree of ethnic fragmentation. Alesina, Baqir, and Hoxby (2000) document how the preference for racial and income homogeneity contributes to determining the choice of borders of municipalities and school districts in the United States. Alesina and La Ferrara $(2000,2002)$ relate the extent of participation in social activities and trust (social capital) to the degree of racial fragmentation in American communities.

An even more depressing interpretation of these results is that different racial groups do not necessarily have different preferences on policies, but simply do not like interactions with members of another group because of racial prejudice.

Obviously the correlation between size and heterogeneity is not perfect. There can be parts of the world in which heterogeneity of preferences is very high even amongst relative small populations (think of the Balkans) or parts of the words were much larger populations are very homogeneous (think of South Korea or Japan). Obviously, the costs of heterogeneity will be binding at very different level of size in different cases. This, amongst many other historical variables, explains why the size of countries varies so much.

Although in this essay I will focus on heterogeneity of preferences rather than on income, the latter plays a key role as well, a point raised by Bolton and Roland (1997). Poor regions would like to join rich regions in order to maintain redistributive flows, while richer regions may prefer to be alone. There is a limit to how much then poor regions can extract due to a non-secession constraint, binding for the richer regions. This point is vastly studied in the literature on localities, especially in the United States. Incidentally this shows that even when one does not observes secessions or border changes, still the forces that determine the choice of borders affect equilibrium polices, for instance the extent of interregional transfers, a point to which we return later.

The trade-off between heterogeneity and benefits of size can shed light on both a normative and a positive discussion of country size. In the former sense, we can think of an optimal size as the one that maximizes over that trade-off between size and heterogeneity. More precisely, we can think of the optimal number and size of countries as the one that would be chosen by a hypothetical social planner maximizing a social welfare function. If the world is modeled as a segment, the population is distributed uniformly, and the social planner maximizes a utilitarian social welfare function in which everybody has the same weight, than every country has the same size. 
From a positive point of view we can ask to what extent the observed organization of borders approximates the condition of optimality. We think of two different concepts of equilibrium: a) voting equilibrium, and b) Leviathans' equilibrium. The former is the configuration of borders that would result in an ideal situation in which borders were determined through majority voting, and in which nobody can impose borders unilaterally or by force. This concept may reflect actual decisions over borders in only a few historical cases. However, even when borders are not determined through direct voting in reality, it provides a useful benchmark to assess the consequences of democratic border redrawing. The second concept of equilibrium (Leviathans' equilibrium) is based on the more realistic assumption for most of history, that borders have been determined by rulers (and the associated elites) who have attempted to maximize their rents, broadly defined.

Let's begin with the Leviathan's equilibrium, where Leviathans are modeled as in Brennan and Buchanan (1980) as rulers who maximize their rents extracted with taxes. Dictators prefer large empires to small countries, because they can extract larger total rents from larger populations: history has witnessed several Emperors whose ideal was to conquer the entire world. However, even dictators face a trade-off between size and heterogeneity. As size increases and the population becomes more heterogeneous it becomes more and more costly for the dictator to avoid reaching a level of discontent in the population that causes an insurrection. This trade-off is one of the determinants of the equilibrium size of empires. In fact, since more heterogeneity makes larger empires more unstable and difficult to hold together by the rulers, the latter may try to reduce heterogeneity by creating, more or less artificially, a sense of "unity." This is why dictators are almost always aggressive internationally and flagwaving nationalists. By emphasizing patriotism by means of propaganda they hope to avoid insurrections of domestic minorities.

A second constraint in the growth of dictatorial empires, in addition to domestic discontent, is of course the conflict with other dictators. Friedman (1977) argues that eventually the land will be distributed "efficiently" in the sense that the dictators who mostly care and have aggressive resources will conquer the most land. Incidentally, often dictators have over expanded, a mistake which in the end resulted in their collapse.

An implication of this is that countries are larger than optimal in a world of dictators, since dictators do not maximize average welfare but their own rents. Thus, democratization and secessions should go hand in hand.

The aftermath of the two world wars of the past century is consistent with this implication. In with the interwar period, a period of collapse of democratic institutions, virtually no new countries were created, despite the nationalistic aspirations left unanswered by the Treaty of Versailles both in Europe and even more in the developing world. In the half a century after the Second World War, instead, the number of independent countries almost tripled and the trend, especially in the last three decades has been toward more democratization 
around the globe. The recent example of the former Soviet Union is rather obvious. Secessions and democratization went closely hand in hand. The same can be said for Czechoslovakia, a peaceful case, and of former Yugoslavia, a not so peaceful one.

A second and related empirical implication is that dictatorial regimes should be more centralized, a result strongly supported by the cross-country empirical analysis by Ades and Glaeser (1995) and Panizza (1999). In fact the former authors show that the only variable that can explain the size of the capital city of a country relative to the size of the country, a proxy for centralization of power is precisely the type of political regimes: dictators have large capital cities. In Spain the process of decentralization could flourish only after the collapse of the Franco regime. After the revolution of 1917 one of the major tasks of the Soviet regime was to centralize power.

What happens, then, in the hypothetical case in which borders are chosen freely and democratically? Can we assume that in a complete democracy borders are necessarily optimal? The answer is "not necessarily."

To fix ideas imagine a country, as a segment on a line were the population is distributed uniformly. Imagine that the line captures both an ideological dimension and a geographical one, that is two individuals who are far from each others in terms of ideology are also far from a geographical point of view. This assumption is very useful to make the world one-dimensional. Moving to a two dimensional world increases the mathematical complexity exponentially with relatively small gain in the intuitive nature of the results. A correlation between geographical distances can be justified in two ways. One is sorting; individuals tend to sort themselves in relatively homogeneous communities, as a vast literature on U.S. localities convincingly shows. The second is that proximity spurs convergence of preferences and local interests.

Suppose that the "government," a term that is meant to capture a bundle of public goods and policies, is located in the middle of the country, which it would be if its location were decided by majority voting. That is, the bundle of policies chosen by the government represents the interests of the median voter who is in the middle of the country. Incidentally, capital cities are often in the middle of the country. Obviously what the "middle" is depends on the distribution of the population and other geographical consideration come into play. Also the relevant "middle" may be the one relevant to the distribution of the population at the time of the formation of the country.

Suppose that the first best, the optimal configuration of borders, maximizes total welfare but the distribution of welfare is uneven, that is, some individuals are very well off and others not so well off. For instance, if everybody has the same income, a fiscal system which does not allow transfers implies that everybody pays the same total income tax. But then, those individuals close to the middle of the country (i.e., close in preferences and in location to the public goods and policies provided by the central government) will be better off than those at the borders. It follows that the latter will have an incentive to vote for 
separation and for reorganization of borders. The "objection" to the existing borders may take several forms: one is unilateral secession, in order to form and independent country or joins an already existing one, another is voting in a referendum to rearrange borders. As a result, in equilibrium there will be smaller countries relative to the optimum.

By the Coase theorem, precisely because the optimal configuration of countries maximizes total welfare, it generates enough total welfare so that transfer schemes between winner and losers can make the optimal number of countries at least weakly preferred to any other configuration of borders.

However, in practice, these transfers' schemes may be difficult to implement, for a variety of reasons. One is a commitment problem. Suppose that transfers are promised to a region-threatening secession. After that region has abandoned the threat, the transfer program can be revoked. To the extent that it is more lengthy and costly to change borders than to change tax laws, there is a commitment problem. An additional critical reason is that to the extent that differences in preferences, rather than income, differentiate regions, it may be difficult to choose the appropriate level of transfers: in fact one runs into a classic problem of revelation of true preferences. To the extent that is geographical distance that matters, the price of land may partially serve the same purpose of transfer schemes, making land cheaper as the distance from the center of the country increases.

The bottom line is that in general one cannot be sure that in a voting equilibrium with a one-person one-vote rule the configuration of borders will reach the first best. If transfer schemes are not available, the voting equilibrium may generate countries, which are too small, precisely, because border regions cannot be "kept in" with appropriate transfers.

\section{Does the Size of Countries Matter for Economic Success?}

The five largest countries (by population) in the world are China, India, the United States, Indonesia, and Brazil. Among them, only the United States is a rich country. By contrast, many of the richest countries in the world are small. Of the ten richest countries in the world, in terms of GDP per capita, only four have populations above 1 million. They are the United States (260 million people), Switzerland (7 million), Norway (4 million people), and Singapore (3 million people). Of these four, two are below average in terms of population. Singapore experienced the second highest growth rate in the world between 1960 and 1990: 6.3 percent per year. During the same period, the fastest growing economies outside East Asia were Botswana (1 million people), with a growth rate of 5.7 percent per year, and Malta (300,000 inhabitants), which, with 5.4 percent, had the highest growth rate in Europe.

Clearly size and prosperity do not go hand in hand. More generally, when and how does the size of a country matter for the economic prosperity of its 
inhabitants? Are small countries economically "viable?" What does the relationship between size and prosperity imply for the equilibrium number and size of countries?

We have argued above that one of the benefits of "country size" is the size of markets. Does the latter, i.e., market size, matter? A large and diverse literature answers "yes" to this question. Romer (1986), Lucas (1988), and Grossman and Helpman (1991) provide models of growth in which various mechanisms imply that a larger size of production increases productivity. Market size is also the key for models of "take-off" of industrialization, as in Shleifer and Vishny (1987). In that model, a certain size of the market (defined by the size of demand) is necessary for entrepreneurs and investors to step in, overcome fixed costs, and spur development.

The relationship between country size and market size depends on the trade regime. In a world of complete autarchy political size and market size of a country coincide. It follows that if a country is small it has a small market. In an economically integrated world, the market size of a country is larger, perhaps much larger, than the political size. In the extreme case, in which borders are totally irrelevant for economic interactions, the market size of each country is the world. If there are economies of scale to the size of the market, larger countries can be expected to do better economically than smaller countries (all other things being equal) insofar as economic integration and international openness are low, but political size should become less relevant as economic integration increases. In other words, the "viable" size of country decreases with economic integration. Note that even in world of free trade national borders do not become irrelevant. The evidence on Canadian and U.S. trade is striking. At least for Canada, national borders still matter; in fact trade among Canadian provinces is much easier than trade between Canadian provinces and U.S. states. Two distant Canadian provinces trade much more with each other than U.S. states and Canadian provinces bordering each other, even though distance is a strong determinant of trade flows. This suggests that free trade makes borders more open but crossing national borders still has a cost in terms of trade flows. Helliwell (1998) summarizes the findings of this line of work. More recent research shows that the border effects may not be so extremely large, but are still quite sizable.

The bottom line is that small countries can prosper as long as they are open to international trade. Conversely, small countries should be especially favorable to maintaining an open world trade regime.

The empirical evidence gathered by Alesina, Spolaore, and Wacziarg (2000) is consistent with implications. They show that country size does not matter for either growth or the level of per capita income when trade is free, but large countries do better if and when they are more closed to trade. These results have implications on the ongoing debate about the relationship between openness and growth, a debate that recently involved among others, Frankel and Romer (1999) and Rodriguez and Rodrik (2001). 
The large increase in the number of independent countries in the postSecond World War has been accompanied by an expansion of world trade and by a sharp increase in economic integration. Economic integration has gone hand-in-hand with political disintegration. Quebec's separatism is a good example. The movement for independence in Quebec was revamped by the implementation of the North American Free Trade Agreement (NAFTA). The freer trade is in North America, the easier it would be for a relatively small country, like Quebec, to prosper. However, as argued before, borders are never completely open and irrelevant for economic transactions. This implies that there might be a cost for Quebec in terms of trade flows if it were to become independent and such arguments were made by the proponents of the "no" in the self-determination referendum of 1996. As the perceived economic costs of secession fall with greater North American economic integration, the likelihood of Quebec gaining independence can be expected to increase. In fact, the development of a true free-trade area in North America might reduce these costs and make Quebec separatism more attractive.

Even more distant history seems consistent with this correlation. Italian cities could prosper as minuscule states because their economies were based upon trade, with a very slim government. In fact these city-states were small very prosperous, open, and relatively democratic economies. A contemporary observer noted how Amsterdam was a place where "commerce is absolutely free, absolutely nothing is forbidden to the merchants ... so when an individual seems to do in his own commercial interest something contrary to the state, the state turns a blind eye and pretends not to notice."

In Italian cities about 5 to 15 percent of the population had voting rights, a sizable percentage similar to the one prevalent in England at the end of the eighteenth century. Also, military technology at the time allowed even relatively small states some level of security, a fact that changed in the sixteenth century, when changes in technology made wars much more expensive, armies larger and more costly. Economies of scale became much more important, leading to the consolidation of the Kings versus the feudal lords. In the new era, the size of states was much more important, than earlier because military public goods were much more expensive. Absolutist regimes needed "size" to support wars and an inward looking economy. So, wars made states as historians are fond of saying.

Outside of Europe, many empires run by Leviathans' ruling class establish themselves without the city-state experience, as in the case of India, China, and the Ottoman Empire. In India the fiscal pressure to finance the extravagant consumption of the ruling elites, was extraordinary, close to 20 percent of GNP, a value which is even by current standard for developing countries. Not surprisingly, an Indian proverb originated then suggests "never stay behind a horse or in front of an official." In all cases, size was the key to ensure sufficient rents to the ruling class and finance wars.

The first half of the nineteenth century sees the victory of liberal ideas and 
the creation of "nation states." The liberal thinkers of the time were keenly interested in the question of the optimal size of nations. They view it as the result of two forces: economic "viability" and homogeneity of culture. Giuseppe Mazzini, the leading figure of the Italian nationalists, argued that the optimal number of countries in Europe that satisfied this criterion was twelve. A famous political economy treaty of the time argues that it was "ridiculous" that Belgium and Portugal should be independent because their economies were too small to be economically viable.

The unification of Germany had of course a lot to do with creating a common market and a defense motive, given the French threat. As for the United States, the Federalist Papers clearly highlight that three motivations underlined the discussion about the need for a federal arrangement for the former colonies:

1) Economies of scale in running the public sector. Alexander Hamilton was especially fond of this argument, which he makes repeatedly. James Madison devoted many pages to argue that one had not to worry about the heterogeneity of interests and preferences in the American federation. Given the American Civil War of 100 years later, one may wonder whether Madison wasn't too optimistic on this point.

2) The second motivation was defense against foreign aggression, a point especially present in John Jay's contribution to the Federalist Papers; in fact Riker's (1964) military interpretation of the American constitution stresses this as the main argument for a federal strengthening of the union;

3) Creation of a common market, a theme emphasized by the classic contribution of Barrington Moore to the study of the American Revolution.

Starting in 1870 the major European powers turns to more protectionist policies. Despite a spectacular reduction in transportation costs, the expansion of international trade comes to almost a complete stop, after the explosion of the previous three decades, because of increasing protectionism. Colonial empires were built in part as a way of insuring markets and as a reaction to an increasing protectionism among European powers. The connection between the increase in trade protection and the need for larger colonial empires seemed clear even to contemporary observers. In a revealing reference, Hobsbawn (1987, page 67) reports that, "If you were not such persistent protectionists," the British premier told the French ambassador in 1897, "you would not find us so keen to annex territories!" Also, flag-waving nationalism of colonial empires helped check centrifugal pressures at home.

The Treaty of Versailles left many nationalistic aspirations unfulfilled both within Europe and, even more, in the developing world. Nevertheless virtually no new countries were created in the interwar period, a period of collapse of free 
trade and of democracy and a very bellicose time. This configuration of events stands in sharp contrast with the decades following WWII. In this period we observe democratization, an increasing trade and financial liberalization, less threat of global war (especially after 1990), and a threefold increase in the number of independent countries. With peace, democracy, and free trade small and relatively homogenous, communities can enjoy independence and prosperity. However, in many parts of the world, especially in Africa, borders seem to cut across ethnic lines in ways that make little sense, because of colonial inheritance. As recently convincingly discussed in Herbst (1998) and in Easterly and Levine (1997), this is one of the reasons for Africa's failure.

Finally, let's pause on the question of the peace dividend. A more peaceful world can be organized in smaller and more numerous states. In fact, being large is especially valuable if much has to be spent on defense, a sector where economies of scale are important. Obviously small countries can (and do) organize themselves in coalitions, but it is certainly safer to be small in a more peaceful world. It is not surprising, then, that the end of the cold war has coincided with an explosion of political separatism. The reduction in the probability of a global confrontation between two superpowers has allowed various regions to seek independence.

Note however, that in a world of many small countries a larger fraction of interactions among individuals and groups become automatically "international": that is they cross national borders. To the extent that there is no international monopoly of coercion, the presence of many more independent small states may lead to more local military confrontations. Thus even though in a more peaceful world the probability that international interactions are belligerent is smaller, there are more international interactions, because countries are smaller. A counterbalancing force is that as small countries need international trade to prosper, they need peace to be able to trade.

\section{The Changing Role of National Borders and the EU}

The role of national governments and, therefore, the meaning of national borders are changing for two reasons. One is that national governments delegate more functions to localities. The other one is that national governments delegate prerogatives to super national institutions. The first issue is vastly explored in the literature on "fiscal federalism," reviewed recently by Oates (1999). The second one is much less studied in the economic literature and it is worth more attention.

Small countries can prosper in a peaceful and economically integrated world. However, such a world needs supranational institutions that enforce free trade and the functioning of markets. This implies that traditional nation states may need to delegate some functions to multinational organizations, such a 
regional or worldwide trade organizations, monetary unions, supranational courts, etc.

Can one argue, therefore, that the nation state is being squeezed both from above from multinational institutions and from below from regional separatism? To some extent the answer is yes: it is becoming fashionable (although not necessarily correct) to argue that the nation states are too big for many functions and too small for many others.

In this respect the European Union represents a special and intriguing case. Fifteen European countries have created a Parliament, a Court system, a Commission, and a Council of Ministers and have delegated to them substantial policy prerogatives. We have argued that more economic integration and the end of the cold war should have lead toward political separatism. How does the European Union "fit" this picture?

First of all, the European Union is not a state, not even a Federal one because it does not have the critical determinant of what a state is: the monopoly of coercion (that is of violence) over its citizens. It is hard to envision that it will ever have this prerogative, especially in an enlarged Europe of twenty-five countries or more.

Second, as economic integration is progressing at the European level, regional separatism is more and more vocal in several member countries of the Union, such as the United Kingdom, Spain, Belgium, Italy, and even France. So much so, that many have argued that Europe will (and, perhaps should) become a collection of regions (Brittany, the Basque Region, Scotland, Catalonia, Wales, Bavaria, etc.) loosely connected within a European confederation of independent regions. In fact, ethnic and cultural minorities feel that they are economically "viable" in the context of a truly European common market, thus they can "safely" separate from the home country. This argument is often mentioned in the press. For an example pertaining to Scotland, see the Financial Times, September 16, 1998: “(. . .) the existence of the European Union lowers the cost of independence for small countries by providing them with a free trade area (...) and by creating a common currency which will relieve the Scots of the need to create one for themselves (...)."

The trade-off between economies of scale and heterogeneity of preferences discussed above offers the proper lenses to analyze the organization of Europe, in particular the attribution of responsibilities between national governments and the European union, as discussed in Alesina and Wacziarg (1999) and especially Alesina, Angeloni, and Schuknecht (2001) and Alesina, Angeloni, and Etro (2001a, 2001b).

The implication of this trade-off is that the appropriate role for the European "government" is limited to those prerogatives for which economies of scale (and externalities) are large, and heterogeneity of preferences low. For instance, the preservation of a common market, antitrust, elimination of any barrier to movement of people and goods within the Union are obvious examples of EU level prerogatives. 
The Euro is an interesting case that illustrates the trade-off. The common currency has advantages due to internalization of externalities (it avoids competitive devaluations) and economies of scale (it facilitates trade). However, it implies that monetary policy cannot be targeted to individual countries' needs and preferences. The decision was made, probably correctly, that economies of scale and internalization of externalities were large enough to overcome the heterogeneity of preferences.

According to the survey evidence analyzed by Alesina, Angeloni, and Schuknecht (2001), the European citizens view the role of the EU in a way consistent with the implication of the above mentioned trade off. They perceive the role of the EU as limited to a few areas mostly having to do with common market policies. Defense and foreign policy is an interesting case. In any federal system, this is "the" function that undoubtedly belongs to the higher level of government. In Europe, which is not a federal state, differences of opinions about foreign policies are so large (think about the United Kingdom and France) that it is hard to imagine any coherent foreign policy at the European level.

So, what does the EU do? Alesina, Angeloni, and Schuknecht (2001) point out several points of departure from an appropriate attribution of responsibilities. The EU government is involved in activities in which the benefits of scale are dubious and heterogeneity of preferences large. Various aspects of fiscal policy and social protection come to mind. In other areas the EU involvement is small, but it is unclear why there should be any, like education and culture and foreign aid just to pick two examples. Also the legislative production of the EU has increased at an exponential rate in the last 3 decades.

How can one explain these departures from principles of optimality? One answer is related to the so-called "democratic deficit." The attribution of prerogatives often is the result of political bargain and conflicts of interest between bureaucracies, more than a well-crafted institutional design. To the extent that the voters are rather removed from the day to day process that leads to the allocation of these prerogatives, the latter are decided in ways that reflect the relative influence of different bureaucracies. The EU level one has an interest in centralizing, while the national level ones have an interest to resists. The outcome of this process reflects the relative weight of these two bodies. The larger the democratic deficit, the more removed from the voters is the EU level government, the more likely it is that we will observe excessive centralization.

Finally, the trade-off between economies of scale and heterogeneity of preferences has very strong implication of the question of enlargement of the union. Enlargement means almost by definition, more heterogeneity of preferences and economic conditions among members. Therefore, one cannot at the same time enlarge and deepen the level of integration. A larger Europe has to imply a less centralized one. 


\section{Conclusion}

The borders of states are a man-made institution that evolves over time in two ways. First, borders change so that the size of countries varies across time. Second, the meaning of national borders changes, i.e., the role of a national government evolves over time. In this paper, which draws on Alesina and Spolaore (1997, 2003), I have offered a point of view to think about these questions. The trade-off between the benefits of size, such as economies of scale, internalization of externalities, military strength, etc., versus the costs of heterogeneity of preferences of the population offers a useful prospective to think about political borders. I argued that combining this trade-off with a set of constraints which define the historical and political landscape sheds light on both a normative and positive model of borders.

The same trade-off is very useful to think about the role of supernational organizations of states in general and the EU in particular. In fact the same trade-off determines the optimal attribution of responsibilities between different levels of government. One can then discuss whether and how the actual experience is consistent or not with the principles of optimality.

\section{References}

Ades, A. and E. Glaeser (1995). "Trade and Circuses: Explaining Urban Giants.” Quarterly Journal of Economics, February.

Alesina, A., I. Angeloni, and F. Etro (2001a). "The Political Economy of Unions,” NBER Working Paper.

Alesina, A., I. Angeloni, and F. Etro (2001b). "Institutional Rules for Federations," NBER Working Paper.

Alesina, A., I. Angeloni, and L. Schuknecht (2001). "What Does the European Union Do?" NBER Working Paper.

Alesina, A., R. Baqir, and C. Hoxby (2000). "Political Jurisdictions in Heterogeneous Communities," NBER Working Paper No. 7859 (August).

Alesina, A., R. Barro, and S. Tenreyro (2002). "Optimal Currency Areas." NBER Macroeconomic Annual, forthcoming.

Alesina, A. and E. La Ferrara (2000). "Participation in Heterogeneous Communities." Quarterly Journal of Economics, August.

Alesina, A. and E. La Ferrara (2002). "Who trusts others?' Journal of Public Economics, August.

Alesina, A. and E. Spolaore (1997). “On the Number and Size of Nations," Quarterly Journal of Economics, 112, pp. 1027-1056, November.

Alesina, A. and E. Spolaore (2003). The Size of Nations. Cambridge, Massachusetts: MIT Press.

Alesina, A., E. Spolaore, and R. Wacziarg (2000). "Economic Integration and Political Disintegration," American Economic Review 90, pp. 1276-1296.

Alesina, A. and R. Wacziarg (1999). "Is Europe Going Too Far?" Carnegie-Rochester Conference Volume, supplement of Journal of Monetary Economics, pp. 1-42, December. Alesina, A. and R. Wacziarg (1998). "Openness, Country Size and the Government.” Journal of Public Economics, 69, pp. 305-322. 
Bolton, P. and G. Roland (1997). "The Break-up of Nations: A Political Economy Analysis.” Quarterly Journal of Economics, November.

Brennan, G. and J. Buchanan (1980). The Power to Tax: Analytical Foundations of Fiscal Constitutions, Cambridge, UK: Cambridge University Press.

Dahl, R. A. and E. R. Tufte (1973). Size and Democracy. Stanford: Stanford University Press.

Easterly, W. and R. Levine (1997). "Africa's Tragedy." Quarterly Journal of Economics, 112, November.

Frankel, J. and D. Romer (1999). “Does Trade Cause Growth?” American Economic Review, June, pp. 379-399.

Friedman, D. (1977). "A Theory of the Size and Shape of Nations," Journal of Political Economy, 85(1).

Grossman, G. and E. Helpman (1991). Innovation and Growth in the Global Economy, MIT Press, Cambridge, MA.

Hamilton, A., J. Madison, and J. Jay (1964), The Federalist Papers. London: Everyman.

Helliwell, J. (1998). How Much Do National Borders Matter? Washington, D.C.: Brookings Institution.

Herbst, J. (1999). States and Power in Africa. Princeton, New Jersey: Princeton University Press.

Hobsbawn, E. J. (1987). The Age of Empires. New York: Vintage Books.

La Porta, R., F. Lopez de Silones, A. Shleifer, and R. Vishny (1999). "The Quality of Government," Journal of Law and Economics, 15, pp. 222-279.

Lucas, R. (1988). "On the Mechanism of Economic Developments," Journal of Monetary Economics, 22, pp. 3-44.

Oates, W. (1999). "An Essay on Fiscal Federalism.” Journal of Economic Literature, September, pp. 1120-1149.

Panizza, U. (1999). "On the Determinants of Fiscal Centralization: Theory and Evidence." Journal of Public Economics, 74, pp. 97-139.

Riker, W. (1964). Federalism. New York: Little Brown.

Rodriguez, F. and D. Rodrik (1999). "Trade Policy and Economic Growth: A Sceptic's Guide to the Cross National Evidence." NBER Macroeconomic Annual. Cambridge, Massachusetts: MIT Press.

Romer, P. (1986). "Increasing Returns and Long Run Growth." Journal of Political Economics, 94, 1002-1037.

Shleifer, A. and R. Vishny (1987). “The Big Push.” Journal of Political Economy, June.

Tilly, C. (1990). Coercion, Capital and European States, AD 990-1990. Cambridge, Massachusetts: Basil Blackwell. 
Copyright of Journal of the European Economic Association is the property of MIT Press and its content may not be copied or emailed to multiple sites or posted to a listserv without the copyright holder's express written permission. However, users may print, download, or email articles for individual use. 